\title{
Význam faktorů trhu práce pro návrat žen na trh práce po rodičovské dovolené 1
}

\section{Labour market factors and the women's work-life strategies after the parental leave}

Blanka Plasová

\begin{abstract}
The aim of this paper is to explore how employment value, workplace characteristics and employers' behaviour intervene in the decision-making process of women in relation to their labour market re-entry after parental leave. I suppose that women perceive the given labour market factors differently with respect to their level of education and that these factors partly influence the final shape of their worklife strategies after (and during) parental leave. Data which we analysed were collected in order to explore the overall mechanism of this decision-making process, which enabled me to find linkages between these factors and the following factors: gender-specific preferences, gender roles and division of work, household financial constraints, overall conditions in the labour market and the role of the institutional context (both formal and informal arrangements). For this purpose, 21 interviews were made, including interviews with women who are currently in transition from parental leave to the labour market, living with a partner in the same household and who had a formal job before taking parental leave. We used a snowball sampling technique to reach the partners for interviews.
\end{abstract}

KEYWORDS Employers' behaviour, employment value, characteristics of working place, parental leave, re-entry in the labour market

\section{Úvod}

V poslední době se mnoho výzkumů věnuje nerovnováze či konfliktu mezi pracovním a rodinným životem. Někteří autoři tento jev zařazují mezi tzv. nová sociální rizika, která se objevují napříč všemi typy moderního sociálního státu (srv. Esping-Andersen 1999; TaylorGooby 2004). Esping-Andersen (1999) hovoří o selhání klíčových institucí současné společnosti (rodiny, trhu práce a sociálního státu) v důsledku přetížení a dysfunkce rodiny, což souvisí i s masivním vstupem žen na trh práce. Tento proces nabourává tradiční dělbu neplacené (péče o děti a domácnost) a placené práce (participace na formálním trhu práce) uvnitř rodiny. Za neplacenou práci byly - a ve většině př́padů stále jsou - zodpovědné hlavně ženy. Nicméně ty nesou navíc i povinnosti vyplývající z výkonu placené práce, což někteří autoři

Sociální studia. Fakulta sociálních studií Masarykovy univerzity, 2/2008. S. 89-105. ISSN 1214-813X.

Vznik tohoto textu byl podpořen výzkumným projektem MPSV ČR (MSM0021622408) Reprodukce a integrace společnosti. 
označují jako tzv. dvojí zátěž žen (srovnej Chaloupková, Šalamounová, 2004; Bartáková 2006). Do dané situace dále přibývají vysoké nároky měnícího se trhu práce, který klade na jedince nároky ve smyslu maximální flexibility vzhledem $\mathrm{k}$ potřebám zaměstnavatelů a ve smyslu kvalifikační úrovně. Je tedy celkem zřejmé, že zejména rodiny s malými dětmi (zhruba do 6 let, kdy je péče o ně nejnáročnější) následně často řeší vyhrocené či konfliktní situace. Finální podoba individuálních strategií rodičů v oblasti skloubení pracovních a rodinných povinností může být determinována mnoha strukturálními, kulturními a institucionálními faktory.

V této stati se budu věnovat okamžiku návratu žen z rodičovské dovolené, respektive okolnostem, které ovlivňují rozhodování o formě a načasování tohoto návratu. Mezi nejvýznamnější teoretické koncepty, které se zabývají vysvětlením chování žen na trhu práce, patří teorie racionální volby (Becker 1981), preferenční teorie (Hakim 2000, 2003) či kulturní teorie (Pfau-Effinger 2004). Každá z těchto teorií zdůrazňuje jako nejzásadnější poněkud odlišný typ intervenujících faktorů. Avšak na základě zmíněných teoretických konceptů, ale i dalších empirických šetření lze shrnout, že jde především o souhru genderově specifických preferencí, hodnot a aspirací týkající se dělby placené a neplacené práce, vlivu převládajících kulturních a sociálních norem, finanční situace domácností, podmínek na trhu práce, chování zaměstnavatelů, charakteru pracovních míst a nastavení a dostupnosti formálních (opatření rodinné politiky, politiky trhu práce, zaměstnavatelů) i neformálních (například výpomoc partnera a prarodičů při zajištění péče o dítě či domácích pracích) opatření směřujících $\mathrm{k}$ harmonizaci práce a rodiny, respektive institucionálního kontextu (srovnej Bartáková, Plasová 2007; Kuchařová et al. 2006; Becker 1981; Chaloupková 2005; Pfau-Effinger 2004, Hakim 2000, 2003 aj.).

Budu se zabývat především vybranými faktory trhu práce, respektive významem zaměstnání, charakteristikami pracovních míst a chováním zaměstnavatelů. Netvrdím, že tyto faktory jsou v rozhodovacím procesu žen naprosto primární, ale at' už jsou prvotními či hlavními hybateli rozhodování preference žen či kulturní normy týkající se rozdělení ženské a mužské práce nebo snaha o maximalizaci užitku/zisku, lze říci, že samotná realizace rozhodnutí či volby žen je významně (spolu)určena shodou, př́ípadně neshodou mezi jejich preferencemi či očekáváním a př́stupem zaměstnavatelů a dostupností pracovních míst s požadovanými charakteristikami (srovnej Kuchařová et al. 2006; Bartáková, Plasová 2007). Tento předpoklad částečně potvrzuje i fakt, že rodiče s předškolními dětmi vnímají ochotu zaměstnavatelů dohodnout se na př́ípadných změnách podmínek práce jako nejzásadnější pro úspěšné sladění pracovních a rodinných povinností (srovnej Hašková, Křížková 2003). Je poněkud diskutabilní označovat význam zaměstnání jako faktor trhu práce, přesto v rámci tohoto textu považuji za významné nejdřive objasnit, jakou váhu ženy svému zaměstnání a participaci na trhu práce přikládají. To se pak totiž dle mého názoru přímo odráží v očekávání žen vůči zaměstnavatelům a v požadavcích na konkrétní charakteristiky pracovních míst.

Obecně je pozice jedinců na trhu práce obvykle determinována úrovní jejich lidského kapitálu a odráží střetávání nabídky a poptávky. V této souvislosti je proto určující chování zaměstnavatelů a jejich potřeby $\mathrm{v}$ oblasti obsazování konkrétních pracovních míst $\mathrm{s}$ určitými charakteristikami. Nicméně postavení žen je v porovnání s muži často zhoršeno právě tím, že zaměstnavatelé anticipují jejich stále převládající zodpovědnost za výkon neplacené práce 
v rodinách a do určité míry mají tendenci k diskriminačnímu chování (zejména v oblasti přijímání zaměstnanců, jejich platovém ohodnocení a kariérním postupu). Tento př́istup pak ženy určitým způsobem reflektují a zanáší do svých strategií v oblasti participace na trhu práce, a tedy i do mechanismů rozhodování o návratu na trh práce z rodičovských dovolených.

Cílem předkládané práce je tedy objasnit, zda a jak vstupuje význam zaměstnání, charakteristiky pracovních míst a chování zaměstnavatelů do mechanismů rozhodování žen o návratu $\mathrm{z}$ rodičovské dovolené zpět na trh práce. $\mathrm{Z}$ důvodu předpokládaného rozdílného př́istupu zaměstnavatelů a návazně i rozdílné dostupnosti určitých typů pracovních míst $\mathrm{z}$ hlediska úrovně lidského kapitálu analyzuji vliv zmíněných faktorů v rámci různých vzdělanostních skupin žen. Je nutné zdůraznit, že daný mechanismus rozhodování žen o návratu na trh práce z rodičovské dovolené je velmi složitý, často velmi individuální proces, daný souhrou velkého množství faktorů, které mají tendenci se v čase určitým způsobem modifikovat a vyvíjet podle měnících se podmínek. Charakter analyzovaných dat mi umožňuje alespoň částečně zachytit i interakce zvolených faktorů trhu práce s dalšími relevantními faktory a okolnostmi.

\section{Metodologická poznámka}

Pro dosažení cíle této stati jsem zvolila kvalitativní strategii výzkumu, která lépe umožňuje odhalit a prozkoumat perspektivu žen s ohledem na jejich proces rozhodování v dané životní situaci. Konkrétně šlo o techniku rozhovoru zaměřeného na celkový mechanismus rozhodování o návratu a jednotlivé relevantní faktory, které mohly hrát v tomto rozhodování nějakou roli. Ve výzkumu jsem zkombinovala tzv. epizodický a strukturovaný typ rozhovoru s otevřenými otázkami (srovnej Hendl 2005). Na počátku rozhovoru bylo hlavním cílem povzbudit ženy $\mathrm{k}$ poměrně volnému vyprávění o vlastních zkušenostech či plánech, týkajících se bud' připravovaného, probíhajícího či už zažitého návratu z rodičovské dovolené na trh práce. Účelem bylo zjistit, která témata budou ženami zmíněna nejdříve. Indikátorem významu konkrétního tématu se stalo pořadí, ve kterém bylo téma respondentkou zmíněno. Následně jsem se postupně podrobně doptávala na další relevantní faktory za účelem jejich maximálního pokrytí. Tento typ otázek byl připraven dopředu, ale jejich pořadí a doslovné znění se dle aktuální situace měnilo z důvodu zachování plynulosti a přirozenosti rozhovoru. V období od léta 2006 do prosince 2007 proběhlo celkem 21 rozhovorů. Výzkumný vzorek zahrnuje 9 žen s vysokoškolským vzděláním, 6 žen se středoškolským vzděláním s maturitou a 6 žen, které dosáhly základního vzdělání či absolvovaly učební obor bez maturity. Vybrané ženy se nacházely v situaci před, $v$ průběhu či krátce po návratu z rodičovské dovolené zpět na trh práce. Dalšími kritérii výběru byly pracovní zkušenost před nástupem na rodičovskou dovolenou a soužití s partnerem ve společné domácnosti.

\section{Význam zaměstnání}

Celý problém otevřu nejdřive vysvětlením významu zaměstnání, ke kterému se pak následně váží i další významné aspekty - zejména důvody a také načasování návratu na trh práce. Na úvod je nutné říci, že oproti významu zaměstnání je význam rodičovství, respek- 
tive mateřství pro všechny ženy naprosto primární. Zájmy a potřeby dítěte zůstávají vždy v popředí, avšak významnou roli v načasování a formě návratu z rodičovské dovolené sehrává individualita každého dítěte.

„Zastávám takový názor (o částečných úvazcích), že když člověk má dobře placenou práci a věděl by, že je o dítě dobře postaráno a to dítě to psychicky dobře snáší.... pokud by to špatně snášelo, tak to ne, to bych zůstala doma“ (...),U toho prvního dítěte bych to využila. Ona byla samostatná, byla ráda mezi děckama, brzo chodila, nepočůrávala se. U malého nemůžu. Taky ne asi od mala. Třeba od těch dvou let, dva a půl.“ (Ludmila, ZŠ)

Ženy, které měly více než jedno dítě např́íklad srovnávaly vývoj a charaktery jednotlivých dětí z hlediska různého objemu, délky a intenzity vhodné péče ve vztahu k možnostem získání placeného zaměstnání. Teprve pokud usoudily, že jsou tyto potřeby dítěte dostatečně uspokojeny a zůstanou v této úrovni i v př́padě návratu na trh práce, zvažovaly hledání vhodného zaměstnání. Jak z rozhovorů vyplynulo, jsou představy o úrovni dostatečně kvalitní péče o dítě/děti v rámci výzkumného vzorku poměrně diverzifikované a možnosti jak této úrovně dosáhnout velmi individuální ${ }^{2}$. Představy o dostatečné a kvalitní péči vycházejí také z názoru dotazovaných žen na to, do jakého věku dítě potřebuje být pouze s matkou, př́padně do jakého věku vyžaduje pouze individuální péči (bud' jiného rodinného př́islušníka než matkou nebo tzv. paní na hlídání) a kdy už je dítě připraveno na kolektivní péči (např. v jeslích či mateřských školkách). Objevovaly se jak názory, že některé dítě, pokud je sociálně zdatné, může být za určitých podmínek št’astné a spokojené v kolektivní institucionální péči už ve dvou letech, tak i názor, že dítě je připravené na „ne-mateřskou“ péči až ve čtyřech letech i déle. Zdá se však, že převážně se ženy snaží zajistit individuální formu péče nejlépe do věku 3-4 let. Podstatné také bylo, jak v tomto ohledu rozdělit zvolený způsob péče mezi matku a jiné aktéry.

„.... podle toho jak to šéfovi bude vyhovovat, protože máme dvě hlídací babičky, takže máme štěstí, že to dítě můžeme někam dát, ale on je tady rád, je to vlastně v tom stejným baráku, takže mu to nedělá žádnej problém jako, že by plakal, naopak ráno vstane a hnedka chce k babičce, nijak nestrádá, že by jako maminka.... a manžel pracuje tady vedle v pracovně, někdy teda odjíždí hnedka ráno, někdy tady dopoledne je, ale i když tady je, tak se mu stejně nemůže věnovat, protože taky pracuje sám. Nechápu, jak někdo říká, že si dal do kanceláře dětskou postýlku, to je hezký, ale na co jí tam má, když se tomu dítěti nemůže věnovat, dejme tomu když spí, to jo, ale....“"(Hana, VŠ).

Celkově lze rríci, že vyjadřovaná potřebnost pouze mateřské péče klesala s rostoucím věkem dítěte. Tyto preference se dále projevovaly v požadavcích na charakteristiky vybraných pracovních míst (více kapitola 2). Teprve v návaznosti na tyto úvahy vyvstala otázka, zda, kdy a v jaké formě se dotyčná žena chce vrátit do práce. Velkou úlohu sehrálo právě to, jaký má zaměstnání pro konkrétní ženu význam, což se obvykle prolínalo s důvody návratu do placeného zaměstnání. Význam zaměstnání byl ženami v dané životní situaci většinou

2 Například v případě, kdy dítě trpí nějakým vážným zdravotním hendikepem (s tímto problémem se potýkaly dvě dotazované ženy). 
spatřován ve smysluplnosti dané aktivity/povolání a spojován s potřebou seberealizace, pocity užitečnosti (jak vůči své rodině tak v širším kontextu celé společnosti, což bylo někdy interpretováno ve vztahu k pocit’ovanému nedostatku společenského uznání matek a ocenění výchovy dětí), s potřebou sociálních kontaktů a v neposlední řadě také s ekonomickým zajištěním rodiny. Tyto významy se v podstatě shodují s nejčastěji uváděnými důvody návratu na trh práce. Mezi další důvody byla často zařazována také potřeba změny, respektive pocit stereotypu a sociální izolace v průběhu rodičovské dovolené. Přestože tyto pocity uváděly téměř všechny ženy, různilo se jejich načasování, což pak také mělo částečně dopad na okamžik alespoň částečného návratu na trh práce. Nicméně je nutné zdůraznit, že vyhledávání pracovního místa nebylo zdaleka jedinou strategií. Některé matky na pocity stereotypu a sociální izolace reagovaly docházkou do mateřských center či absolvováním nejrůznějších vzdělávacích a zájmových kurzů (např. složení zkoušky na řidičský průkaz).

„No prostě už jsem byla hrozně unavená tou neustálou starostí a už mě ten stereotyp ubíjel a měla jsem pocit, že bych na něho měla být milejší a klidnější a všechno mu to do nekonečna vysvětlovat a pořád po něm do nekonečna uklízet a já jsem se vždycky rozč́lila a už jsem cítila, že už to nemůžu vydržet, že jsem cítila, že už mě to jako nenaplňovalo nebo už jsem cítila i taková nevytížená, i když to dítě vás samozřejmě vytíží, ale .....

Když člověk na chvíli vypadne, tak je i takovej odpočinutější, sice je zase unavenej jinak, ale je psychicky takovej ..." (Hana, V̌̌)

Lze říci, že význam finančního ohodnocení se v souvislosti s významem zaměstnání i v souvislosti s důvodem návratu na trh práce sice téměř vždy objevil (v závislosti na konkrétní ekonomické situaci domácnosti), ale nezdá se, že by byl primární. Nutnost návratu do placeného zaměstnání byla také jednou odůvodňována nutností zabezpečit finančně rodinu, pokud by došlo například k jejímu rozpadu. Pokud odlišíme ženy dle stupně jejich vzdělání, finanční motiv návratu byl častěji zmiňován méně vzdělanými ženami, kdy šlo většinou o dostatečné množství financí pro uspokojení materiálních potřeb dítěte a rodiny.

A jak to vzniklo, že jste začala chodit na brigádu? Proč jste se pro to rozhodla? (tazatelka) „Protože těch 3800 bylo hodně málo a chtěli jsme jít do většího bytu. Měli jsme 2+ kk. A naskytla se nám výměna v baráku. Což je výhoda, že se nemusí měnit občanky. Bylo cítit, že peníze chybí. Někdo se uskromní, ale já chci dětem dopřát. Neumím říct, tady máte jedny bonbóny na den. Když peníze mám, koupím jim dvoje.“ (Zita, vyučena)

Na druhou stranu pocity seberealizace byly těsněji spojovány s placeným zaměstnáním kvalifikovanějších žen. Některé ženy také poukazovaly na provázanost pocitů stereotypu a úrovně péče o dítě. Objevoval se názor, že pokud žena na rodičovské dovolené trpí těmito pocity a touží se realizovat právě v placené práci a podaří se jí takovou práci najít, pak je spokojenější či št'astnější jak ona sama, tak i dítě.

„.....a taky je to (zaměstnání na částečný úvazek) prostě stres a už asi dvakrát jsem si ř́kala, že já jsem sem lezla, proč jsem nezůstala doma na mateřské a po třech hodinách doma si říkám dobře, že jsem tam šla, doma bych nevydržela, takhle budu klidnější, př̌ivětivější a víc vydržím jako 
matka“..... Od té doby, co pracuji, tak mi přijde, že je (dítě) větší sluníčko než předtím, člověk se na něj víc těší..." (Hana, VŠ)

Argumenty podobného typu někdy využívaly k vysvětlení i matky, které se cítily svým okolím kritizovány či negativně posuzovány z důvodu dřívějšího návratu na trh práce, než je obvyklé.

\section{Význam charakteristik pracovních míst}

V této části přiblížím představy a potřeby žen, týkající se charakteristik pracovních míst (zejména $\mathrm{v}$ termínech délky, flexibility a obsahu), a to at' už v průběhu rodičovské dovolené nebo těsně po jejím ukončení. Celkem překvapivé bylo zjištění, že více než polovina žen ve výzkumném vzorku měla $\mathrm{v}$ průběhu rodičovské dovolené nějaké placené zaměstnání. Jako dř́vější návrat na trh práce $\mathrm{z}$ rodičovské dovolené bude dále označována jakákoli placená práce žen v tomto období. Pro přehled lze říci, že 5 z 9 vysokoškolaček a 3 z 6 středoškolaček a 4 z 6 vyučených žen nebo se základním vzděláním pracovalo nějakým způsobem dřive než ve 3 letech dítěte Většinou šlo o velmi nízký rozsah této práce (téměř ve všech př́padech to byla určitá forma brigády, výpomoci či velmi krátký úvazek - několik hodin týdně či 1-2 dny v týdnu). Jak již bylo řečeno, rozsah a načasování tohoto zaměstnání byly spoluurčovány rozhodnutím ženy vzhledem k potřebám dítěte a dostupnosti vhodné „ne-mateřské“ péče o dítě. Převážná většina žen vyjádřila zájem o částečné úvazky, zdůrazňovala jejich výhody a mnohé z nich by možnost pracovat touto formou chtěly už při rodičovské dovolené, což indikuje zájem o dřívější návrat na trh práce, ale pouze za určitých podmínek, které si následně více přiblížíme. I přesto některé ženy naprosto odmítly možnost pracovat dřive než ve 3. či 4. roce věku dítěte a dobu rodičovské dovolené chtěly plně věnovat pouze péči o dítě, což je plně uspokojovalo a nevysledovala jsem v tomto směru žádné větší odchylky dle vzdělanostní úrovně žen.

„Myslím si, že by to (částečné úvazky v průběhu rodičovské dovolené) určitě bylo lepší i z toho sociálního hlediska kvůli těm ženským. Nebyly by tak frustrované, nezapomněly by mluvit, lépe by se uplatnily na trhu práce. Když by šly na dvě hodiny týdně! Na ten kontakt by nezapomněly. Č́m mohou být, jak se prosazovat.“ (Helena, SŠ)

Společně požadovaná vlastnost placeného zaměstnání v průběhu rodičovské dovolené byla v každém prŕípadě maximální volnost a flexibilita v době výkonu práce, a to často nejen $\mathrm{v}$ jednou dané volbě začátku či konce práce, ale také v organizaci času ze dne na den. Z těchto důvodů také některé ženy volily určitou formu podnikání ${ }^{3}$ či sebezaměstnávání (například v podobě soukromé výuky cizích jazyků). Dá se říci, že dostupnost takových forem zaměstnání měly především více kvalifikované ženy, a také šlo o ženy, které dle svých slov potřebovaly udržet kontakt s profesí z důvodu rizika ztráty své kvalifikace. Ženy s nižším vzděláním, pokud pracovaly dříve než ve 3 letech věku dítěte, získaly spíše zcela nekvalifikované

3 V jednom př́padě žena začala sice podnikat už před porodem prvního dítěte, ale pokračovala v této činnosti i po narození dítěte. 
zaměstnání ve formě brigád (např́íklad úklid), někdy bez formální pracovní smlouvy. Ženy tyto formy zaměstnání často našly pouze díky své „sociální síti“, respektive šlo o doporučení známého, zaměstnal je rodinný př́islušník (manžel, otec) nebo šlo o bývalého zaměstnavatele. Také často nešlo o zcela pravidelnou práci, ale spíše o formu občasné výpomoci (např́ílad občasné noční služby v nemocnici).

Potřeba co největší flexibility a možnosti kontroly nad pracovní dobou ve vztahu k placenému zaměstnání zůstává primární i v období po rodičovské dovolené, nicméně preferovaný objemu času v placeném zaměstnání významně roste. Přestože i v tomto období by ženy často uvítaly možnost pracovat ve zkráceném pracovním režimu, není to již absolutně nutné za předpokladu, že by se jim povedlo získat na plný úvazek takové pracovní místo, které je v daném ohledu dostatečně pružné.

Rozhodovala jste se nebo přemýšlela jste o tom částečném úvazku nebo jste rovnou šla do plného? (tazatelka)

„Ne říkám, že chodím po obojím. Říkám, to prostě záleží na tom, jak ta pracovní doba bude nastavená. Já jsem to vlastně nedořekla, drogerie Jasmín myslím, hledala skladovou referentku. Tam to bylo postavený tak, že je tam volná pracovní doba. Tak to by mě jako vyhovovalo, já tam můžu být dvanáct hodin denně, když je manžel doma, ale zase budou dny, kdy je budu muset vyzvednout ve čtyři ze školky." (Eva, SŠ)

Co největší volnosti v organizování dělby času mezi práci a rodinu jsou ženy ochotny obětovat i možnost návratu na původní, garantované pracovní místo. Zejména pokud byly charakteristiky původního pracovního místa ve výrazném rozporu se zajištěním péče o dítě (vyzvedávání dítěte ze školky a celková délka pobytu v mateřské školce), což dále souviselo i s charakteristikami pracovních míst partnerů (zejména časová náročnost jeho zaměstnání vzhledem $\mathrm{k}$ možnostem se alespoň částečně podílet na každodenní péči o dítě). Některé ženy byly z tohoto důvodu ochotné jít i tzv. pod úroveň své kvalifikace, a to i v prrípadě nižšího finančního ohodnocení. Ze strachu, že nenaleznou dostatečně časově flexibilní pracovní místo, plynuly největší obavy z návratu na trh práce. V př́padě kvalifikovanějších žen byla někdy znát nejistota, co se týče potřebných znalostí. Na druhou stranu měly snahu se na návrat určitým způsobem připravit a doufaly v rychlé překonání pracovní přestávky.

A jaký byl návrat na ten trh práce po 5,5 letech, překvapilo vás něco, jaký to pro vás bylo? (tazatelka)

„Po té odborné stránce si myslím, že jsem se vrátila tím, že jsem si dělala ten kurz bezprostředně před tím než jsem dělala ty konkurzy, takže jsem to měla v hlavě, takže jsem i ty odborné věci zvládla. A co mě překvapilo, co po mně nechtěli před lety po škole, tak chtějí obsluhu počítače, ale jako word, excell, ale hodně do podrobností, ne jenom nějakou tabulečku, rovnou nějakou supertabulku a já jsem fakt jako dělala úplně základy. Takže když po mně chtěli něco, tak jsem se to doučila a někde po mně zase chtěli něco jiného, takže tohle mě docela překvapilo, to se určitě posunulo za tu dobu, aspoň v tom mým oboru. Ale zase je to asi tím, že je tady spousta zahraničních firem a posílají se všude možně reporty a výkazy a to zrovna je tady v těch excellovských souborech, takže je to kvůli tomu.“ (Květa, VŠ)

Ve smyslu odborné přípravy na návrat z rodičovské dovolené se ve výzkumném vzorku objevovaly celkem pochopitelné rozdíly v závislosti na specifičnosti profese té které ženy. 
Vysokoškolačky většinou nenavštěvovaly kolektivní kurzy, které se jim zdály příliš všeobecné, ale spíše si na konci rodičovské dovolené snažily samy „osvěžit“ své původní znalosti. Ženy, jejichž povolání nevyžadovalo tak úzce specializované odborné znalosti, často navštěvovaly tzv. kurzy pro maminky ${ }^{4}$, které v současné době poskytuje mnoho neziskových organizací, a snažily se naučit zacházet především s výpočetní technikou a běžně užívanými počítačovými programy. Dále šlo také o kurzy v oblasti daní a vedení účetnictví či cizích jazyků a motivační kurzy. Ženy, jejichž práce před rodičovskou dovolenou byla nějakým způsobem spojena se znalostí cizích jazyků, nejvíce pocit'ovaly výrazné riziko její ztráty. Právě v těchto př́padech se některé dotazované ženy snažily udržovat úroveň znalosti cizího jazyka pomocí soukromé výuky po celou dobu rodičovské dovolené. Celkově však ženy pocit’ovaly nedostatek času na tuto formu přípravy a soustředily se na ni až v samém závěru rodičovské dovolené.

„Že jsem měla ty děti tak jako relativně blízko po sobě a neměla jsem zas tak velkou možnost jako hlídání během té mateřské, tak jako bych to definovala tak, že jsem moc času, že bych si po večerech studovala, jako moc neměla." (Simona, VŠ)

\section{Chování zaměstnavatelů}

Dostupnost preferovaných a vhodných pracovních míst je do velké míry závislá na chování zaměstnavatelů. To, jak ženy vnímají chování zaměstnavatelů, jaký mu přikládají význam a také jaká mají vůči nim očekávání, ovlivňuje jejich zájem o návrat na trh práce.

Nejdříve se zaměříme na to, jak ženy vnímají celkové postavení žen a mužů na trhu práce. Až na jednu výjimku všechny ženy vnímaly rozdílné postavení žen a mužů na trhu práce. Často se objevoval názor, že se v poslední době tyto rozdíly zmírňují, zejména v horizontální rovině, což znamená, že svět práce není již tak striktně rozdělen na čistě mužská a ženská povolání. Vnímání některých rozdílů nadále přetrvává. Například právnička z našeho výzkumného vzorku se nejednou setkala s postojem, že muž - právník bude u rozvodového stání tvrdší soupeř, protože je muž, a získá tak více, než by získala žena. Důvody rozdílné pozice mužů a žen na trhu práce se většinou vztahovaly k tradiční dělbě práce - zejména v oblasti péče o děti. Ženy ve všech vzdělanostních kategorií se naprosto shodly v tom (jak názorově, tak na základě vlastních zkušeností), že nejčastěji jde především o kontinuitu pracovní dráhy, která je u žen přerušena mateřskou a rodičovskou dovolenou, a dále zajištěním péče o nemocné děti. Jak rodičovská dovolená, tak péče o nemocné děti jsou přitom vnímány jakožto odpovědnost ženy. Tyto okolnosti pak zaměstnavatele vedou k tomu, že ženy pojímají jako rizikovou pracovní sílu, a to at' už v kontextu reálného či pouze předpokládaného mateřství.

Zase z toho, co jste ř́kala, tak mám pocit, že se domníváte, že muži a ženy mají na trhu práce jiné podmínky u zaměstnavatelů... (tazatelka)

4 Nicméně je důležité poznamenat, že naše technika výběru výzkumného vzorku může ovlivňovat míru příprav. Několik žen s nižším než vysokoškolským stupněm vzdělání bylo právě z těchto kurzů a ty nám doporučily další účastnice. 
„Jo, no. Tak muži tím, že nemají ty děti“ (Petra, VŠ).

Ale oni mají ty děti... (tazatelka)

„Oni je mají taky, ale nikdo jim je jako nepřišije, jakoby tam se to nebere, že ten muž s tím dítětem bude doma, že to ... a samozřejmě finančně je ten muž taky někde jinde než ta žena, byt' dělají stejnou práci.“( (Petra, VŠ)

Tento předpoklad se pak podle žen odráží zejména v procesu přijímání nových zaměstnanců a v platovém ohodnocení. Často se objevoval názor, že svou roli hraje charakter oboru a konkrétního pracovního místa, kdy ve feminizovanějších oborech a tam, kde se mzdy vyplácí tzv. tabulkově, nejsou rozdíly uplatňované zaměstnavatelem tak velké. Zajímavý byl také názor, že zaměstnavatelé finančně ohodnotí muže více právě proto, že „živí rodinu“, na rozdíl od ženy, kde fakt, že má děti, vede k opačnému výsledku.

Liší se postavení žen a mužů na trhu práce obecně? (tazatelka)

„Liší se. Je známo, že chlap vydělá na stejné pozici jako žena víc. Je to ještě tak, že je tu zavedené, že chlap zvládne víc. Žena má být doma. Což tak dávno není. Bude dlouho trvat, než se to změní. ...S manželem jsme dělali ve stejné práci a on bral, nechci říct jednou tolik, ale ...a byli jsme tam hodinově stejně“ (Kateřina, vyučena)

A proč to tak je? (tazatelka)

„Nevím, těžko říct. Vždycky byl chlap víc, než ženská. Ženská byla vždycky posluhovačka. Většinou to bylo tak, že ženská měla rodit a starat se o plotnu a chlap byl ten živitel rodiny... Neř́kám, že je to ve všech zaměstnání. Jsou i ženy, které vydělávají slušně, ale to není můj př́ípad. $\mathrm{S}$ dvěma dětmi kariéru neuděláte. Já bych kariéru v kuchařině neudělala, tak jsem se rozhodla pro ty děti.“" (Kateřina, vyučena)

Mezi dalšími důvody odlišnosti mezi muži a ženami byl uváděn také věk. Tento aspekt ženy vztahovaly $\mathrm{k}$ trendu mateřství až v pozdějším věku a opět $\mathrm{k}$ dlouhému přerušení pracovní dráhy, kdy se ženy cítí diskriminovány i z důvodu vyššího věku. Také byl zmíněn názor, že u žen je častěji důležitý fyzický vzhled než u mužů.

Obecně lze říci, že ženy od zaměstnavatelů neočekávají př́liš velké ústupky, které by jim umožňovaly lépe zvládnout práci i rodinu, respektive kontinuální př́stup přátelský k rodině. Nicméně každý, byt' sebemenší vstř́ícný krok, je velmi pozitivně hodnocen a oceňován. Zde se pravděpodobně odráží i to, že ženy přisuzují zodpovědnost za sladění práce a rodiny většinou pouze sobě (rodině) a případně státu (srovnej Hašková, Kř́ižková 2003). Ženy se s výrazně vstř́icným prrístupem zaměstnavatelů vzhledem k jejich potřebám v oblasti slad'ování práce a rodiny prŕliš nesetkávaly, zejména ženy s nižším stupněm vzdělání. Nicméně téměř všechny ženy by tuto snahu velice ocenily a dle svých slov by se ji bránily jakkoli zneužívat, což také často označily za jeden z důvodů, proč se zaměstnavatelé zavádění prorodinných opatření brání.

Já jsem teda řekla, že budu pracovat ten fond a on s tím počítá, že to hlídání tady nemám, a kdyby náhodou byl nějaký problém, tak že se domluvíme... No, uvidíme, jestli ta zkušenost bude tak, jak to ř́kal. Snad jo. Taky je to o tom, že já se snažím vždycky v životě nezneužívat situace, co nastane, takže si myslím, že když nebudu zneužívat a doopravdy to budu potřebovat, tak mi snad pomůže. Když si ale člověk řekne: tenkrát mi pomohl, tak to zkusím zase, tak asi by byl problém (Martina, SS̆). 
Naopak by se více snažily svoji ,problémovost“ (potřeba úprav pracovní doby nebo nutnost zajištění péče o děti v př́padě nemoci) zaměstnavatelům nějakým způsobem kompenzovat, třeba v podobě co největšího pracovního nasazení nebo v podobě přesčasů.

„Takže si myslím že, ...nevím, domnívám se, že v mým případě to třeba půjde, ale pokud by ... a samozřejmě se budu snažit teda dělat co nejvíc, co budu moct. Zase proto, abych když třeba někdy budu s tím dítětem doma, tak aby si řekli dobře, ale svoji práci odvedla, tak ted' hold bude týden doma, ale dělá, jak nejvíc může, no ted’ je doma, no tak ale, ale až se nám vrátí, tak zase bude dělat teda, jak nejlíp umí. Takže tak jako. Opravdu se asi teda budu snažit, tehdy jsem to možná brala víc tak lehkovážněji, jo. Bude, nebude, budu nebudu." (Petra, VŠ)

Dle názoru některých žen jsou v tomto ohledu zaměstnavatelé ovlivněni také tím, že pokud existuje velký zájem o určité pracovní pozice a zaměstnavatelé si mohou vybírat, nemají důvod se prŕliš přizpůsobovat matkám s dětmi a raději si počkají na takového uchazeče, který nebude mít problémy a nadstandardní potřeby v oblasti sladění práce a rodiny.

„Spíše si myslím, že jsou lidé, kteří chtějí jít do práce a chtějí se se zaměstnavatelem domluvit, že by třeba o půl hodiny přišel později a pak si to napracoval. V tom by zaměstnavatel mohl vyhovět, ale většinou to na tomto ztroskotá." (Ludmila, ZŠ)

A proč si myslíte, že na to nechce přistoupit? (tazatelka)

„Nevím. Mě to přijde, že si dá svoje podmínky a bude tak dlouho čekat, až se tam někdo chytne.

Protože hodně lidí hledá práci a najde.“ (Ludmila, ZŠ).

Důvody, které by naopak zaměstnavatele mohly k takovému chování vést, ženy spatřovaly především ve vlastní zkušenosti zaměstnavatelů s nutností skloubit práci a rodinu. Některé ženy v našem výzkumu dokonce samy byly v pozici zaměstnavatele a uvedly, že na základě vlastní zkušenosti byly více ochotné se domluvit se svými zaměstnankyněmi s dětmi a vytvořit vhodné podmínky. Dále tyto, ale i další ženy usuzovaly, že tím, že zaměstnavatel vyjde do určité míry vstř́ic potřebám matky s dítětem, má možnost si udržet zkušenou zaměstnankyni. Tím se vyhne problémům s vyhledáváním a zaučováním jiného, spolehlivého člověka. Tento výsledek koresponduje s nejčastěji uváděnými důvody, proč zaměstnavatelé daná opatření zavádějí (srovnej např. Den Dulk 2001; Anxo et al. 2006; Osterman 1995 aj.). Mezi další důvody, které uváděly hlavně ženy s nižším vzděláním, byla zařazována kompenzace nízkého finančního ohodnocení pracovní pozice v oblasti, kde je nízká nabídka práce. Zaměstnavatel je pak dle zkušeností žen spíše ochoten dohodnout se na určité úpravě podmínek. Často ženy vyjadřovaly velkou míru pochopení i pro zaměstnavatele, kteří nejsou ochotni jim vyhovět téměř v ničem. Zejména pokud uznaly, že jejich požadavky by mohly narušit chod firmy/organizace či snižit zisk. Ovšem na druhou stranu byly někdy rozhořčeny tím, že jim zaměstnavatelé nechtěli ustoupit ani v maličkostech, a to i v př́padě, že by drobná výhoda (oproti zaměstnancům bez dětí) neměla na chod společnosti negativní vliv.

„Pokud k němu (zaměstnavateli) přijde člověk, který má o práci zájem, a chce jen malou výhodu - vím, že by si na něj mohli druzí kvůli jeho výhodám ukazovat prstem - ale zase se to dá velice jednoduše vysvětlit. Ta půl hodinka - nám z vesnice třeba nejede zrovna vlak - není moc velká úleva. Pokud by to byl dobrý pracovník a on by s ním byl spokojený, tak bych to tak viděla.“ (Ludmila, ZŠ) 
Jako ústřední byla $\mathrm{v}$ tomto ohledu často zmiňována role státu, který by měl vytvořit takové podmínky, aby se zaměstnavatelům vyplatilo matky s malými dětmi zaměstnávat na tak často preferované částečné úvazky. V souvislosti s potřebou intervence ze strany státu byla také často uváděna povinná garance pracovního místa v průběhu rodičovské dovolené. Zaměstnavatel sice nemůže ukončit s rodičem pracovní smlouvu, ale v okamžiku návratu - dle zkušeností žen - najde zaměstnavatel nějaký způsob, jak ženě znemožnit pokračovat v zaměstnání.

A co by ten stát měl udělat, aby Vám pomohl? (tazatelka)

„Já si myslím, že by měla být větší jistota, že mě do té práce vezmou. Že bych neměla mít ten strach z toho, že mě nevezmou. To, že mě zanikla firma, fajn, ale pak jsem zas zažila, že Vám končí zaměstnání, firma nezanikla, ale dáváme Vám výpověd', protože jste byla tři roky doma. Toto je podle mě problém. Oni mi tři roky drží zaměstnání, já si myslím, že budu moct nastoupit, a oni mi dají výpověd'." (Martina, SŠ)

Otázka načasování a formy návratu na trh práce je spojena také s tím, zda se ženy vracely $\mathrm{k}$ původnímu zaměstnavateli či si z různých důvodů hledaly místo nové. $Z$ dat vyplynulo, že možnost návratu $\mathrm{k}$ původnímu zaměstnavateli mají výrazně častěji ženy s vyšším vzděláním. Tento výsledek koresponduje i s výsledky jiných výzkumů, kdy např. Kuchařová (et al. 2006) uvádí, že v průměru pouze $25 \%$ žen se vrací po nebo během rodičovské dovolené k původnímu zaměstnavateli ${ }^{5}$ (a $12 \%$ dosáhne dohody o pozdějším návratu než ve 3 letech dítěte). Celkově se však k původnímu zaměstnavateli do 3 let vrací $63 \%$ vysokoškolaček, ale pouze 26 \% vyučených žen a jen 10 \% žen se základním vzděláním. Pouze jedna vysokoškolačka a dvě středoškolačky ve výzkumu uvedly, že se po rodičovské dovolené nemají kam vrátit, a to $\mathrm{z}$ důvodu zániku původního zaměstnavatele. Nicméně téměř všem vyučeným ženám či ženám se základním vzděláním a jedné středoškolačce nevznikl před mateřstvím takový pracovní poměr, který by zaručoval alespoň relativní možnost návratu. V tomto výsledku se může odrážet obecně horší postavení méně kvalifikovaných jedinců na trhu práce s ohledem na kvalitu pracovních míst, která může být dále zhoršena horizontální a vertikální segmentací dle genderu v neprospěch žen (srovnej Bartáková 2006; Kuchařová, Zamykalová 2000 atd.). Tato skupina žen byla nucena $v$ okamžiku návratu hledat nové pracovní místo na volném trhu práce. Některé z nich měly i zkušenost s úřady práce, kterou hodnotily víceméně negativně s ohledem na rozsah pomoci při hledání zaměstnání. Objevil se také náznak přebírání některých diskriminačních praktik zaměstnavatelů.

„Potom jsem šla žádat na pracák a samozřejmě mě nechali na pracáku půl roku. Tam mě nenabídli vůbec nic a pořád mi tvrdili, že jsem mladá, že budu mít druhý a že to nemá cenu, abych šla někam do práce. Takže to byly většinou brigády...". (Ludmila, ZŠ).

A jak jste na to reagovala, když Vám říkali takové věci? (tazatelka)

„Dá se říct, že jsem se rozčilovala, ale bylo to k ničemu. Řekli mi, at’ si najdu práci nebo „chod’te k nám, my Vás zaevidujeme, podíváme se do počítačů.“ Když se podívali, tak oni tam samozřejmě

18 \% ukončí pracovní poměr a zůstane s dítětem/dětmi déle v domácnosti, $20 \%$ žen přechází plynule na druhou rodičovskou dovolenou s dalším dítětem, $15 \%$ si hledá jiné zaměstnání a $10 \%$ žen nemělo před narozením dítěte žádnou pracovní smlouvu (Kuchařová et al., 2006). 
napíšou, že mám dítě, kolik mám roků, čím jsem vyučená nebo nejsem vyučená a na tom základě zjistila, že mě nikdo nechce. Nebo tak mi to alespoň odůvodňovala, ale to spíš bylo odůvodňování její. Práce by se dala najít, někdo by se i přesto, že nejsem vyučená, našel.“ (Ludmila, ZŠ).

Při vyjednávání o možné úpravě pracovních podmínek ženy často uváděly jako výhodu, pokud je dotyčný zaměstnavatel již znal a měl pozitivní zkušenost s jejich pracovním nasazením. Tento zaměstnavatel pak byl dle jejich názoru více ochotný vyhovět požadavkům s ohledem na usnadnění harmonizace práce a rodiny.

„....protože je tam ta výhoda, o které jsem mluvila, že vás ten člověk zná. Jestli je s vámi spokojený, tak vám, podle mě, tu pracovní dobu vždycky přizpůsobí. Když jdete jinam, nic o vás neví. Třeba jste šikovná, ale nezjistí to, protože vám nedají šanci.“" (Stela, vyučená).

Nyní se zaměřím na to, s jakou reakcí se ženy setkaly v momentě, kdy projevily zájem či potřebu se nějakým způsobem vrátit na trh práce. Odliším situace, kdy šlo bud' o tzv. dřivější návrat $\mathrm{v}$ průběhu rodičovské dovolené nebo o návrat ve 3.(4.) roku věku dítěte, tedy po celé rodičovské dovolené. Více než polovina žen ve výzkumu měla nějaké placené zaměstnání dříve než ve 3. roku dítěte, tento podíl se nijak nelišil v závislosti na vzdělání žen. $\mathrm{V}$ tomto ohledu je nutné znovu podotknout, že v období rodičovské dovolené neměly ženy $\mathrm{v}$ žádném príípadě zájem pracovat na plné úvazky. Poměrně zajímavý je fakt, že v tomto období ženy pouze ojediněle pracovaly pro svého původního zaměstnavatele (pokud ho měly). U žen $\mathrm{s}$ nižším vzděláním je tento fakt pochopitelný vzhledem $\mathrm{k}$ tomu, že před rodičovskou dovolenou neměly - kromě jedné výjimky - takové zaměstnání, které by garantovalo možnost návratu. $\mathrm{V}$ případě vysokoškolaček se $\mathrm{v}$ jednom případě objevila nabídka původního zaměstnavatele (střední škola) na občasnou výpomoc, nicméně žena tuto nabídku odmítla. Další vysokoškolačka dostala príležitost pracovat ve své původní firmě, ovšem tato situace byla specifická tím, že majitel firmy byl zároveň její otec. A pouze jedna středoškolačka během rodičovské dovolené chodila vypomáhat na své původní pracovní místo. Nejvíce se ženy uchylovaly ke strategiím, které jim umožňovaly maximální stupeň volnosti organizovat si čas dle svých potřeb a potřeb dětí. Ve čtyřech př́padech tedy šlo určitou formu podnikání (soukromá výuka angličtiny, kosmetický salón, výroba skleněných figurek), kde byly ženy dle svých vlastních slov „paní svého času“. Nabízí se tedy úvaha, že ženy volily jiné strategie kvůli tomu, že původní zaměstnavatelé nebyli príliš ochotní (z různých důvodů) jim takovou (flexibilní) práci poskytnout. Tento předpoklad se částečně potvrzuje tím, že se ženy i po ukončení rodičovské dovolené nesetkávaly se vstř́cným postojem původních i potenciálně nových zaměstnavatelů vzhledem ke svým potřebám rozdělení především času mezi práci a rodinu. I v tomto období ženy často vyjadřovaly potřebu zkrácení či alespoň posunutí pracovní doby především kvůli zajištění péče o dítě (hlavně šlo o provozní dobu mateřských škol). Pokud však se zaměstnavatelem nedospěly k oboustranně přijatelné domluvě, pak byly svým způsobem donuceny $\mathrm{k}$ hledání nového zaměstnání i ženy, které se sice hypoteticky mohly vrátit do původního zaměstnání, avšak z uvedeného důvodu nemohly/nechtěly na toto místo zpět nastoupit. $\mathrm{V}$ tomto prípadě se částečně projevily rozdíly $\mathrm{v}$ rámci vzdělanostních skupin žen. Zdá se, že lepší výsledky ve vyjednávání v ohledu úpravy pracovních podmínek měly ženy s vyšším stupněm vzdělání. Více než polovina žen s vysokoškolským vzděláním, které se vracely k původnímu zaměstnavateli, nakonec dosáhla alespoň malých ústupků. 
Zároveň byla patrná větší ochota zaměstnavatelů jim vyjít alespoň částečně vstříc. Někdy byla patrná tendence zaměstnavetele ženy od jejich požadavků zrazovat.

„No, nelíbilo se jim to. Dělala jsem speciální vyšetření, které málokdo uměl - a tu práci, která tam byla jsem si stejně musela odvést, takže mi primář řekl: „Ježíš, to si rozmyslete, kdybyste se vrátila na zkrácený, chtěl bych po vás stejný výkon jako na plný a měla byste mín̆ peněz. To já neumím ovlivnit“. (Helena, SS̆)

V tomto okamžiku se pozastavil proces návratu u některých žen, pro něž bylo vhodné pracovní místo z různých důvodů nedostupné. Ženy v dané situaci zvažovaly strategii pobírat rodičovský příspěvek až do čtvrtého roku života dítěte a využít toto období pro hledání vhodného zaměstnání. Př́ipadně využít tohoto období pro důkladnější přípravu na návrat v podobě nějakého vzdělávacího kurzu nebo pracovat ve formě brigády nebo - pokud byla taková možnost dostupná - nějakého velmi krátkého úvazku. Zde sehrála významnou roli dostupnost zajištění péče o dítě bud' v mateřských školách ${ }^{6}$ nebo pomocí prarodičů (nejčastěji pomocí babiček). Obtížnost zajištění vhodné péče se ještě ve dvou prŕípadech značně zkomplikovala poměrně závažnými zdravotními problémy dítěte. Tyto ženy se sice snažily vhodnou práci najít, ale po několika neúspěšných pokusech o skloubení práce se zajištěním zvýšené péče o dítě rezignovaly. Snažily se dosáhnout maximálního prodloužení rodičovské dovolené na 7 let z důvodu špatného zdravotního stavu dítěte či získat dávky určené na péči o závislou osobu. Dalším ,ک̌rešením situace“ bylo navazující těhotenství. V této souvislosti se však samozřejmě projevil i vliv časté preference mít děti věkově co nejblíže. Zde tedy můžeme do určité míry vysledovat tzv. skrytou nezaměstnanost, a to v případě žen, které sice preferovaly návrat na trh práce, ale z důvodu nedostupnosti vhodného zaměstnání zvolily raději 4. rok pobírání rodičovského příspěvku či navazující rodičovskou dovolenou. Ženy s nižším vzděláním při zvažování, zda pobírat rodičovský příspěvek 4. rok, zdůrazňovaly častěji jeho výši (od 1. 1. 2007 zhruba 7600 Kč) s možností reálného výdělku. Přesto nelze říci, že tato okolnost byla zcela primární.

Dále se budeme věnovat situaci, kdy ženy hledaly po ukončení rodičovské dovolené nové zaměstnání. Několikrát se objevila výrazná obava z neúspěchu, a to zejména z důvodu zajištění péče o děti hlavně v souvislostí s jejich očekávanou nemocností častou hlavně v předškolním věku. Tato skutečnost přitom, dle názoru žen, zaměstnavatele nejvíce odrazuje. V př́padě žen, jejichž kvalifikace je citlivá k dlouhému přerušení práce, sehrála svoji úlohu také nedůvěra ve schopnost zvládnutí dané práce.

A čekala jste nějaký problémy než jste šla to zaměstnání hledat?

Velký ...tím, že mám děti, že budou nemocný, že nemám babičky na hlídání, že jsem sedm let nepracovala, přesně to, co tam probíhalo, doopravdy jsem tam čekala problém...Že jsem účetní

6 Tato varianta, tedy současné pobírání rodičovského př́spěvku a zajištění péče o dítě v mateřské škole či podobném zařízení je umožněna teprve od 1. 1. 2006 novelou č. 204/2005, která zrušila původní omezení ,předat část celodenní a řádné péče o dítě“ do rukou zařízení pro děti př̀edškolního věku (jesle, MŠ) pouze na 5 dní v měsíci. Dítě, které dovršilo 3 roky věku, může nyní pravidelně navštěvovat mateřskou školu nebo jiné obdobné zařízení v rozsahu nepřevyšujícím 4 hodiny denně (Zákon č. 117/1995). 
a nemám ted' tu daňovou problematiku čerstvě. S těma děckama to bylo asi to nejhorší, to potřeboval (zaměstnavatel u pohovoru) hodně prodiskutovat. Ale pak mi zase dal najevo, že když budou problémy, že si můžu vynahradit odpoledne, sobotu... (Martina, SŠ).

Obecně se ženy velmi často setkávaly při přijímacích pohovorech s otázkami směřujícími $\mathrm{k}$ at' už každodennímu zajištění péče o dítě v návaznosti na pracovní dobu či v době jejich nemoci, což se dle jejich názoru jeví jako pro zaměstnavatele zcela zásadní informace. Ženy - jak už bylo výše řečeno - pro pokládání těchto otázek ze strany zaměstnavatele často projevovaly pochopení. Na druhou stranu, pokud měly k dispozici pomoc prarodičů, někdy trochu paradoxně kritizovaly to, že tento fakt zaměstnavatele nezajímal a automaticky předpokládaly problém. S diskriminačními praktikami hlavně v rámci přijímacích pohovorů se osobně setkala více než polovina žen v našem výzkumném vzorku, i když je nutno poznamenat, že tyto otázky byly často vnímány jako něco naprosto přirozeného a ženy je nevnímaly jako projev diskriminujícího př́stupu.

„No tak určitě diskriminace, sice se říká, že není, ale když někde řeknete, že máte malý děti, tak si každý spočítá, ano fajn malý děti - nemoc! Když nemáte babičky, tak jste pořád doma. Ted' měly neštovice, bylo zkouškový období, stejně to musím odzkoušet, stejně to za mě nikdo neudělá, takže pro mě nebylo vůbec výhodný si brát nějaký OČR (asi ošetřování člena rodiny)! Ti studenti by na mě byli naštvaní, museli by sem jezdit někdy v červenci, zbytečnost. Tak jsem to řešila těma babičkama, ale kdo je nemá, tak chudák zaměstnavatel, protože já kdybych jim tady řekla, že jeden to měl 3 týdny a druhý potom 3 týdny, tak jste vlastně dva měsíce mimo kvůli neštovicím. A to není žádná závažná choroba, může to být horší. Takže si myslím, že je to pro tu ženskou přítěž.“ (Tamara, VŠ)

\section{Závěr}

Můžeme říci, že se ve strategiích a rozhodovacích procesech žen $v$ daném ohledu do určité míry odráží zákonitosti nabídky a poptávky na trhu práce. Kvalifikovanější ženy jsou v kvalitnějších a více chráněných pracovních místech, což jim dává výhodu oproti ženám s nižším stupněm vzdělání. Většinou se mají kam po rodičovské dovolené vrátit a pokud s nimi mají zaměstnavatelé pozitivní zkušenost, více stojí o jejich návrat a jsou ochotni vyjít vstř́í jejich požadavkům a potřebám v oblasti pracovních podmínek. Na druhou stranu může být jejich kvalifikace citlivější $\mathrm{k}$ dlouhému přerušení práce, $\mathrm{z}$ čehož někdy plynou obavy ze ztráty či zastarávání kvalifikace během dlouhé rodičovské dovolené. Méně kvalifikovaným ženám se většinou nenaskytla možnost návratu do původního zaměstnání, a to bud' z důvodu nechráněného či méně kvalitního pracovního místa $\mathrm{v}$ období před rodičovskou dovolenou nebo z důvodu zániku původního zaměstnavatele, príípadně proto, že jim zaměstnavatel nebyl ochoten poskytnout úpravy pracovních podmínek. A proto jsou některé ženy nuceny hledat jiného zaměstnavatele. Přitom musí překonat v podstatě dva druhy hendikepu - fakt, že mají malé děti, a předpoklad vysoké nemocnosti dětí a dále nízkou kvalifikaci. Na druhou stranu jsou ochotné vzít v podstatě jakoukoli práci, jen aby jim umožnila skloubit pracovní a rodinný život. Objevila se strategie volit taková zaměstnání, kde se zaměstnavatelé potýkají s problémem získání pracovníků (např. kvůli nízké mzdě). Tito zaměstnavatelé jsou pak ochotni se domluvit na určitých ústupcích. 
Společným jmenovatelem požadavků na charakteristiky pracovních míst v období kdy jsou děti malé je co největší volnost, flexibilita ve výkonu a možnost maximální kontroly nad pracovní dobou. Důvodem je zajištění vhodné péče o děti (tedy zejména časová a prostorová dostupnost mateřských škol a jiných zařízení) a dostupnost pomoci v péči o dítě ze strany partnera či prarodičů. Aspekt volnosti v organizování práce je nejvýznamnější právě pro placená zaměstnání $\mathrm{v}$ průběhu rodičovské dovolené, ale zůstává důležitou charakteristikou preferovaných pracovních míst i po jejím ukončení. Lze také konstatovat, že je mezi ženami velký zájem o zkrácené úvazky, a to jak během rodičovské dovolené, tak i v určitém období po jejím ukončení nejčastěji do školního věku dítěte. Avšak pokud nahlédneme do statistik či do publikací s danou tematikou, můžeme říci, že v porovnání se zeměmi EU je celkový podíl zaměstnanců v režimu zkráceného pracovního úvazku v ČR velmi nízký7. Důvodů, proč tomu tak je, může být samozřejmě více. Mezi ty nejzásadnější může patřit jejich obecně nízká kvalita (srovnej Zamykalová, Polívka 2000; Kuchařová et al. 2006), nezájem zaměstnavatelů či neprovázanost s možností zajištění péče o dítě. Zejména vzdělanější matky s dětmi mohou být odrazeny, pokud je jejich záměrem tzv. udržovací strategie z důvodu rizika zastarání kvalifikace. Na druhou stranu pro ženy s nižším vzděláním mohou být taková místa neatraktivní kvůli velmi nízkému finančnímu ohodnocení, kdy se právě pro tyto ženy zdá finanční motiv návratu na trh práce $\mathrm{z}$ rodičovské dovolené důležitější. Celkově však množství času, které ženy chtějí investovat do placeného zaměstnání, postupně roste se zvyšujícím se věkem dítěte.

Dostupnost či nedostupnost těchto míst pak spoluurčuje načasování návratu na trh práce v okamžiku, kdy ženy pocit’ují z různých důvodů potřebu nějakého placeného zaměstnání $\mathrm{v}$ průběhu rodičovské dovolené. Tato charakteristika pracovního místa je naprosto rozhodující i po ukončení rodičovské dovolené s ohledem na volbu bud' zkráceného či plného pracovního úvazku nebo návratu na původní místo, př́ípadně vyhledání místa nového.

\section{Literatura}

ANXO, Dominque ; BOULIN, Jean-Yves ; FAGAN, Colette ; CEBRIÁN, Inmaculada ; KEUZENKAMP, Saskia ; KLAMMER, Ute ; KLENNER, Christina ; MORENO, Gloria ; TOHARÍA, Luis. Working time options over the life course: New work patterns and company strategies. European Foundation for the Improvement of Living and Working Conditions. Luxembourg : Office for Official Publications of the European Communities, 2006. 129 s. ISBN 9289709286.

BARTÁKOVÁ, Helena. Faktory ovlivňujici chování žen po rodičovské dovolené ve vztahu k trhu práce.[rukopis - rigorózní práce]. Brno : Masarykova univerzita, 2006.

BARTÁKOVÁ, Helena ; PLASOVÁ, Blanka. Mechanismy rozhodování žen s vysokoškolským vzděláním o přechodu z rodičovské dovolené na trh práce. In: MAREŠ, Petr, HOFÍREK, Ondřej (eds). Sociální reprodukce a integrace: ideály a meze. Sborník z konference. Brno : Masarykova univerzita, Mezinárodní politologický ústav, 2007.

Např́iklad v roce 2003 v průměru EU-25 pracovalo v režimu zkráceného pracovního úvazku 30,5 \% všech zaměstnaných žen (6,6 \% mužů), ale v ČR pouze 8,5 \% žen (2,3 \% mužů) (ČSÚ 2004). 
BECKER, Gary S. A Treatise on the Family. Cambridge, Mass: Harvard University Press, 304 s. 1981.

DEN DULK, Laura. Work-family arrangements in organisations: A cross-national study in the Netherlands, Italy, the United Kingdom and Sweden, Netherlands. School for Social and Economic Policy Research, Thela-Thesis, 2001. 223 s. ISBN 9051705425.

ESPING-ANDERSEN, Gosta. Social Foundations of Post-Industrial Economies. 1. vyd. Oxford : Oxford University Press, 1999. 207 s. ISBN 0198742010.

HAKIM, Catherine. Lifestyle Choices in the 21st Century. Oxford : Oxford University Press, 2000. 360 s. ISBN 0199242100.

HAKIM, Catherine. Models of the Family in Modern Societies: Ideals and Realities. Ashgate, 2003. 282 s. ISBN 0754644065.

HAŠKOVÁ, Hana ; KŘÍŽKOVÁ, Alena. Průzkum veřejného mínění o postavení žen na trhu práce. Praha : Sociologický ústav AV ČR, 2003. 47 s.

HENDL, Jan. Kvalitativní výzkum: základni metody a aplikace. 1. vyd. Praha : Portál, 407 s. ISBN 80-7367-040-2.

CHALOUPKOVÁ, Jana ; ŠALAMOUNOVÁ, Petra. Postoje $k$ manželství, rodičovství a $k$ rolím v rodině v České republice a v Evropě. 1. vyd. Praha : Sociologický ústav AV ČR, 2004. $60 \mathrm{~s}$.

CHALOUPKOVÁ, Jana. Faktory ovlivňující dělbu domácí práce v české společnosti. Sociologický časopis, 2005, č. 1, s. 57-77. ISSN 0038-0288.

KUCHAŘOVÁ Věra ; ZAMZKALOVÁ, Lenka. Rovnost př́ležitostí žen a mužů na trhu práce. Praha : VÚPSV, 2000. 20 s.

KUCHAŘOVÁ Věra ; ETTLEROVÁ, Sylva ; NEŠPOROVÁ, Olga ; SVOBODOVÁ, Kamila. Zaměstnání a péče o malé děti z perspektivy rodičů a zaměstnavatelü: zpráva z výzkumu realizovaného jako součást projektu „Programu Iniciativy Společenství EQUAL“ Role rovných príležitostí pro ženy a muže v prosperitě společnosti (Pưl na pưl). 1. vyd. Praha : VÚPSV, 2006. 112 s. ISBN 80-87007-18-2.

O státní sociální podpoře. Zákon č.117/1995 Sb. [online]. 1995, [cit. 2005-04-30]. Dostupná na www: < http://i.iinfo.cz/urs-att/p_117-95-114816789736980.htm >

O státní sociální podpoře. Zákon č.204/2005 [online]. 2005, [cit. 2005-04-30]. Dostupná na www: < http://i.iinfo.cz/urs-att/p_117-95-114816789736980.htm >

OSTERMAN, Paul. Work/Family Programs and the Employment Relationship. Administrative Science Quarterly, 1995, s. 681-700. ISSN 00018392.

PFAU-EFFINGER, Brigit. Development of Culture, Welfare States and Women's Employment in Europe. Aldershot: Ashgate. 2004. ISBN 0754616932.

POLÍVKA, Milan; ZAMYKALOVÁ, Lenka. Vytvářeni odpovidajicich podmínek pro uplatňování pružných forem organizace práce a pracovní doby jako součást politiky zaměstnanosti. Příloha 3. Praha : Výzkumný ústav práce a sociálních věcí, 2000. $22 \mathrm{~s}$.

Práce, sociální statistiky. Český statistický úr̆ad [online]. 2004, [cit. 2005-04-30]. Dostupná na www: < http://www.czso.cz/csu/edicniplan.nsf/aktual/ep-3 >

TAYLOR-GOOBY, Peter. New Risks and Social Change. In TAYLOR-GOOBY, P. (ed.) New risks, new welfare: the Transformation of the European Welfare State. New York : Oxford Univerzity Press, 2004. 262 s. ISBN 019926726X. 


\section{Autorka}

Blanka Plasová je studentkou postgraduálního studia oboru sociální politika a sociální práce na Fakultě sociálních studií Masarykovy univerzity v Brně, kde také působí při Institutu pro výzkum integrace a reprodukce společnosti. Zabývá se především tématy týkající se harmonizace pracovního a rodinného života $\mathrm{z}$ perspektivy rodičů a zaměstnavatelů a institucionální péčí o děti mladší 3 let.

Kontakt: plasova@fss.muni.cz 